\title{
The Investments Efficiency Toward Economic Growth: ICOR of the Republic of Croatia and Slovenia - Comparative Analysis
}

\author{
Jeton Mazllami \\ Faculty of Business and Economics South East European University \\ Republic of North Macedonia, Tetovo \\ j.mazllami@seeu.edu.mk
}

\begin{abstract}
Most developing and developed countries, today are faced with a lot of economic, social, and political challenges as a result of internal or external factors such as the World Financial Crisis and Covid19. In these circumstances, the crucial objective of any government is to improve the national economic performance by increasing domestics and foreign investments. Investments efficiency is the main pillar in the increase of the economic growth of any economy.

This paper aims to measure the efficiency of the investments towards economic growth in the Republic of Croatia and Slovenia by applying a comparative analysis. The specific objective of our paper is to determine the best ICOR level, the correlation between ICOR and GDP, and the impact on the economic growth of both countries.

The research methodology will include the analysis of the efficiency of the investment measured by the indicators Incremental Capital-Output Ratio (ICOR) based on the World Bank approach. The period of observation includes the period from the year 1995 to 2020. The investment efficiency (ICOR) in both countries is expected to move between 1 and 6 . The findings of this research are that each one-point decrease of the ICOR level of Croatia increases the economic growth by 1.961 percent, while the ICOR level of Slovenia increases less the Economic growth by 0.259 percent.
\end{abstract}

Keywords: efficiency, investment, GFCF, ICOR, GDP growth.

JEL Classification: E22, H54, O46 


\section{Introduction}

The allocation and reallocation of financial resources as well as their efficient utilization perhaps is one of the main issues of management on the micro and macro level. Investment efficiency is a crucial issue for companies' managers and national public finance policymakers. From a microeconomic point of view, making adequate and efficient investment decisions is among the greatest challenges for managers in the world. On the other hand, for local and central governments, the efficiency of public investments is a crucial challenge of good governance. Overall, the good governance of private and public investments is a pillar for stable economic growth and development.

The efficiency of investments is directly reflected in the final output of each company and the national economy as a whole. There are some financial indicators in an overall estimation of the productivity of investments. In this way, one of the most common economic indicators, which measures investment efficiency is the Incremental Capital-Output Ratio (ICOR). Investment efficiency means more final output with less investment so that with less investment capital will realize more marginal outcomes effects (Mazllami, 2007).

Republic of Slovenia and Croatia compared to other republics of former Yugoslavia have achieved the best performance in fulfilling the economic and political criteria of the EU. The economies of these countries are developed based on prudent economic policies. Worth stating that both these economies, from the moment of independence from Yugoslavia, have managed to attract and develop a lot of domestic and foreign investments.

The subject of this research is the efficiency of investments in the economic growth of Croatia and Slovenia. The best indicator which measures investment efficiency is ICOR based on GCF (Gross Capital Formation) or GFCF (Gross Fixed Capital Formation).

This research will address the following questions: What is the impact of investments on economic growth in these economies? What is the investments efficiency situation? Has the economy of the Republic of Slovenia performed better in efficiency compared to the economy of the Republic of Croatia? The answers to these questions will be understood during this research. To answer for investment efficiency, we will analyze the best ICOR score for both countries during the period between the years 1995 to 2020 . During the period of our analysis, we should focus our attention on 2009 as a breaking point of the economic growth for both economies as a result of the negative effects of the global financial crisis. Undoubtedly, the next period until 2018 will be marked as a recovery period of economic growth but unfortunately in 2019, the whole world faced the COVID-19 pandemic with very serious consequences on human health and economies as a whole.

We can surely state that the limitation of this scientific work is the relatively small number of variables incorporated in the ICOR model. The difficulty during the work has been the lack of existing research dedicated to the efficiency of investments in the Western Balkans, based on the ICOR indicator. On the other hand, we can say that this paper fills the gap of research in this field.

\section{Literature review}

Since the pioneering works of R. Harrod (1939) and E. Domar (1946), through the works of N.R. Kaldor (1957), R. Solow (1956), E. Phelps (1961) and, thirty years after, the birth of the endogenous growth theory P. Romer (1986), R. Lucas (1988), R. Barro (1988), Bencivenga \& Smith (1991), to its most recent developments (theories of "pro-poor" growth and "inclusive" growth) and the "alternative" growth theories (Setterfield, 2010), productive investment, labor has always been regarded as the pillar engine of growth along (Berthomieu et al., 2016). 
During the last two decades' economic researchers have been dedicated to measuring the efficiency of investments through ICOR. The World Bank in investment reports for many countries analyses investment efficiency as a very important indicator of economic growth. From a lot of research papers is noteworthy that today's ICOR's indicator for developing economies is usually higher but for developed economies is low because they are more efficient and effective in the exploitation of investments. Unfortunately, it is worth noting that there is a gap in terms of research dedicated to investment efficiency in the Western Balkans and beyond.

In the following section, we present the authors who have contributed to the research of the efficiency of investments based on the ICOR indicator in Western Balkan and Europe.

Ivo Vinski (1961) is considered the first researcher who provided a concrete estimation of all physical assets in former Yugoslavia from the year 1909 to the year 1951. According to his assessment, the ICORE value has moved between 4.5 and 7.5 .

Lovrinčević et al. (2004) in their paper have calculated the ICOR for Croatia for the period 1994 - 2002. According to them, the average ICOR value for Croatia was 4.9.

Antiochou (2011) has calculated ICOR for Croatia, Albania, Bosnia and Herzegovina, FYROM, and Serbia for the period 1998 - 2009. His estimate was based using mean real growth rates and net fixed capital investment series.

Gabrisch (2014) has calculated the value of ICOR on the one hand for Western Balkan countries with Croatia and on the other hand Czech Republic, Hungary, Poland, Slovak Republic, and Slovenia as new EU members. The author has made a comparison among Western Balkan countries and has found surprisingly low ICOR values. It is worth noting the ICORE values 0.7 for Serbia and a negative ICORE value for Macedonia.

Ivanovic (2015) has found that the ICOR coefficient in Croatia has an increasing trend, this means that the efficiency of domestic investment fell and that FDI leads to a decrease in domestic investment.

Berthomieu et al. (2016) has calculated the value of ICOR for WB countries during the period 2001-2012. This period was used as the reference period to calculate mean growth rates and average net investments and a one-year lag was used as suggested by the literature. The results obtained from their research show strange results in Serbia and Macedonia one unit of output is produced with less than one unit of physical capital and thus that the stock of capital is used more efficiently than in the United States or Germany.

Nikolic \& Kovacevic (2019) have analyzed the ICOR based on GFCF. The focus of their study was the $\mathrm{EU}$ and the case of the Serbian economy. They have measured the ICORE of the public and private sectors and after that the total ICOR. They concluded that for dynamic economic growth it is necessary to increase the investment rate but most important is to make productive and efficient investments.

Mazllami \& Aziri (2019) in their research paper have assessed the value of ICOR for the Republic of North Macedonia and the Republic of Albania. The authors conducted a comparison between the efficiency of investment of North Macedonia and Albania. The period of their research was 1993-2017. The authors' findings were that the Republic of North Macedonia has the 13th best ICOR values compared to the Republic of Albania with the 7th. In general, the efficiency of the investments after the financial crisis from the year 2009 to the year 2017 in both countries was very low.

\section{Methodology of the Empirical Research}

Nowadays, a large number of researchers calculate investment efficiency by utilizing the incremental capitaloutput ratio (ICOR). The incremental capital coefficient falls within a group of non-simultaneous marginal capital coefficients. This indicator represents the ratio between the discrete increment of fixed capital $(\Delta K)$ and the growth of gross domestic product $(\Delta \mathrm{Y})$ so that the capital increase is measured for the previous 
year ( $t-1)$ while the growth of the gross domestic product is measured for the current year ( $t$ ) (Mazllami, 2019).

Table 1. Formulas of measure investment efficiency

\begin{tabular}{|c|c|}
\hline $\operatorname{ICOR}=\frac{K_{n-1}-K_{m-1}}{Y_{n}-Y_{m}}=\frac{\Delta K}{\Delta Y}=\frac{\stackrel{\Delta-1}{n-1} K_{\underbrace{}_{m}}^{n} Y}{\Delta}$ & $\begin{array}{l}\text { - The time interval ( } \mathrm{t}) \text { for ICOR calculation is defined } \\
\text { as the period }(\mathrm{n}-\mathrm{m}) \text {. Current year }(\mathrm{n}) \text {, Year ago }(\mathrm{m}) \text {. } \\
\text { - }(\mathrm{K}) \text { is the value of Gross Fixed Capital Formation, } \\
\text { - }(\mathrm{Y}) \text { is the Gross Domestic Product (GDP). }\end{array}$ \\
\hline $\mathrm{ICOR}=\frac{\mathrm{GFCF}_{\mathrm{t}-1}}{\mathrm{GDP}_{\mathrm{t}}-\mathrm{GDP}_{\mathrm{t}-\mathbf{1}}}$ & $\begin{array}{l}\text { - } \text { Gross Fixed Capital Formation (GFCF) } \\
\text { - } \quad \text { Gross Domestic Product (GDP) } \\
\text { - } \quad \text { Current year (t), Previous year (t-1) }\end{array}$ \\
\hline $\mathrm{ICOR}=\frac{\mathrm{GI}_{\mathrm{t}-1}}{\Delta \mathrm{Y}}=\frac{\mathrm{GCF}_{\mathrm{t}-1}}{\mathrm{GDP}_{\mathrm{t}}-\mathrm{GDP}_{\mathrm{t}-\mathbf{1}}}$ & 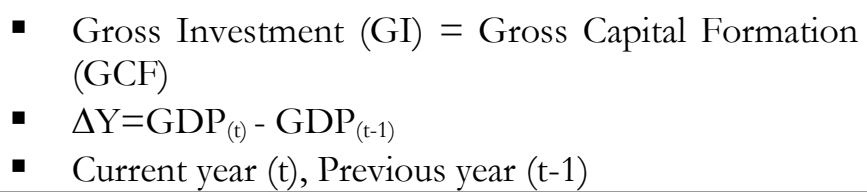 \\
\hline
\end{tabular}

Source: Authors' work based on World Bank (2018)

According to the ICOR rules, if the ICOR value is low, then the GDP growth is expected to be high and vice versa. Additionally, in cases where the ICORE value is negative, the situation of the national economy is characterized by disinvestment and recession.

The Republic of Slovenia is a member of the EU earlier than Croatia, which provides us with the assumption that the impact of ICOR Slovenia on GDP growth is higher than that of Croatia. The model of measuring the impact of ICOR on GDP growth includes only two variables. In this way, we will use the OLS method of estimation of the one-factor econometric model. The simple classic econometric model has therefore the following form:

$$
Y_{i}=\beta_{0}+\beta_{1} X_{1}+u_{i}
$$

If in the equation "(1)" we would replace the dependent variable $(\mathrm{Y})$ with a nominal growth rate of GDP (g) and the independent variable $\left(\mathrm{X}_{1}\right)$ with ICOR, then we can obtain the equation "(2)":

$$
g_{i}=\beta_{0}+\beta_{1} \operatorname{ICOR}_{i}+u_{i}
$$

\section{The efficiency of investments (ICOR) of the Republic of Croatia and Slovenia}

The study aims are to provide an analysis of the value of the ICORR in Croatia and Slovenia with a comparative approach. From the measurements of the empirical research, we should result in answers to our research questions and assumption.

The research period for both countries is between the years 1995 and 2020. According to the formulas depicted in Table 1, the measurement of ICOR will be assessed on these relevant variables depicted in Table 2. 
Table 2. Description of variables

\begin{tabular}{|l|l|}
\hline \multicolumn{1}{|c|}{ Symbols } & \multicolumn{1}{c|}{ Description } \\
\hline GCF & Gross Capital Formation (Euro) \\
\hline GCF $(\%$ of GDP) & Gross Capital Formation (\% of GDP) \\
\hline GFCF & Gross Fixed Capital Formation (Euro) \\
\hline GFCF $(\%$ of GDP) & Gross Fixed Capital Formation (\% of GDP) \\
\hline GDP & Gross Domestic Product (Euro) \\
\hline GDP (a.g. $\%$ ) & GDP (annual nominal growth rate $\%$ ) \\
\hline GDP $($ a.g. $\%)$ & GDP (annual real growth rate $\%$ ) \\
\hline ICOR & Incremental Capital Output Ratio $(>0)$ \\
\hline
\end{tabular}

Source: Author's interpretation, based on Eurostat Database, 2021

\section{Data, Investments background and GDP growth in the Republic of Croatia}

The investments and economic growth on the economy of the Republic of Croatia during the period 1995 - 2020 have had a positive trend with three breakpoints on 1997, 2009, and 2019 (see Table 3):

- There is a positive trend of Gross Capital Formation on average of 8.76 billion $€$ and an average of $23.37 \%$ of GDP, where $\mathrm{GCF}_{\mathrm{Min}}=3.0$ billion $€$ in the year 1995 , and $\mathrm{GCF}_{\mathrm{Max}}=14.75$ billion $€$ in the year 2008.

- There is a positive trend of Gross Fixed Capital Formation an average of 7.83 billion $€$ and is an average of $20.89 \%$ of GDP, where $\mathrm{GFCF}_{\mathrm{Min}}=2.5$ billion $€$ in the year 1995 , and $\mathrm{GFCF}_{\mathrm{Max}}=13.53$ billion $€$ in the year 2008 .

- There is a positive trend of nominal GDP growth rate from 1996 till 1997, 1999 until 2008 and from 2010 till 2019. The negative GDP growth rate is recorded in the years 1999 (-3.55\%), 2009 ($5.96)$ and $2020(-9.46 \%)$.

Analyzing the line trend of GCF and GFCF (Chart 1), we can conclude that from the year 1995 to the year 2008 Croatia marks growth, but with a small deviation while from the year 1998 to the year 1999 they cross down. From the year 2010 until 2014 the positive trends were changed as a result of the impact of the global financial crisis. Unfortunately, during this period, the Croatian economy showed negative net investments (GCF-GFCF), therefore this period was called disinvestment. The state of these indicators was changed with a growing tendency and a significant positive difference between GCF and GFCF from the year 2014 until the year 2019. The situation has worsened in the year 2019 as a result of the COVID-19 pandemic which will hurt the health of citizens and the economy in general.

Table 3. GCF, GFCF and GDP growth of the Republic of Croatia

\begin{tabular}{|c|c|c|c|c|c|c|c|}
\hline Year & $\begin{array}{c}\text { GCF } \\
(\mathrm{mil} €)\end{array}$ & $\begin{array}{c}\text { GCF } \\
(\% \text { of GDP })\end{array}$ & $\begin{array}{c}\text { GFCF } \\
(\mathrm{mil} €)\end{array}$ & $\begin{array}{c}\text { GFCF } \\
(\% \text { of GDP })\end{array}$ & $\begin{array}{c}\text { GDP } \\
(\mathrm{mil} €)\end{array}$ & $\begin{array}{c}\text { GDP nom } \\
(\text { a.g. } \%)\end{array}$ & $\begin{array}{c}\text { GDP real } \\
(\text { a.g. } \%)\end{array}$ \\
\hline 1995 & $3,004.80$ & 17.18 & $2,500.90$ & 14.30 & $17,488.80$ & n.d. & n.d. \\
\hline 1996 & $3,911.40$ & 20.53 & $3,486.00$ & 18.30 & $19,049.18$ & 8.92 & 5.90 \\
\hline 1997 & $5,416.90$ & 25.61 & $4,569.60$ & 21.60 & $21,155.56$ & 11.06 & 6.20 \\
\hline 1998 & $4,983.50$ & 21.87 & $4,762.80$ & 20.90 & $22,788.52$ & 7.72 & 2.30 \\
\hline 1999 & $4,705.30$ & 21.41 & $4,659.70$ & 21.20 & $21,979.72$ & -3.55 & -0.90 \\
\hline 2000 & $4,735.50$ & 20.23 & $4,704.00$ & 20.10 & $23,402.99$ & 6.48 & 2.90 \\
\hline 2001 & $5,510.20$ & 21.44 & $5,293.60$ & 20.60 & $25,697.09$ & 9.80 & 3.00 \\
\hline 2002 & $7,039.40$ & 24.78 & $6,364.00$ & 22.40 & $28,410.71$ & 10.56 & 5.70 \\
\hline 2003 & $8,642.40$ & 28.12 & $7,929.00$ & 25.80 & $30,732.56$ & 8.17 & 5.60 \\
\hline 2004 & $9,004.70$ & 26.92 & $8,597.40$ & 25.70 & $33,452.92$ & 8.85 & 4.20 \\
\hline 2005 & $9,847.30$ & 26.96 & $9,276.20$ & 25.40 & $36,520.47$ & 9.17 & 4.30 \\
\hline
\end{tabular}




\begin{tabular}{|c|c|c|c|c|c|c|c|}
\hline 2006 & $11,730.40$ & 29.21 & $10,683.30$ & 26.60 & $40,162.78$ & 9.97 & 5.00 \\
\hline 2007 & $12,763.90$ & 29.06 & $11,771.70$ & 26.80 & $43,924.25$ & 9.37 & 5.10 \\
\hline 2008 & $14,746.60$ & 30.75 & $13,525.90$ & 28.20 & $47,964.18$ & 9.20 & 1.90 \\
\hline 2009 & $11,336.30$ & 25.13 & $11,366.80$ & 25.20 & $45,106.35$ & -5.96 & -7.30 \\
\hline 2010 & $9,540.80$ & 21.13 & $9,573.70$ & 21.20 & $45,158.96$ & 0.12 & -1.30 \\
\hline 2011 & $8,958.20$ & 19.95 & $9,069.90$ & 20.20 & $44,900.50$ & -0.57 & -0.20 \\
\hline 2012 & $8,277.20$ & 18.83 & $8,617.70$ & 19.60 & $43,967.86$ & -2.08 & -2.40 \\
\hline 2013 & $8,494.40$ & 19.43 & $8,610.70$ & 19.70 & $43,709.14$ & -0.59 & -0.40 \\
\hline 2014 & $8,222.40$ & 18.99 & $8,356.50$ & 19.30 & $43,297.93$ & -0.94 & -0.30 \\
\hline 2015 & $9,193.10$ & 20.55 & $8,721.30$ & 19.50 & $44,724.62$ & 3.30 & 2.40 \\
\hline 2016 & $9,800.20$ & 21.07 & $9,350.30$ & 20.10 & $46,518.91$ & 4.01 & 3.50 \\
\hline 2017 & $10,830.50$ & 22.05 & $9,824.30$ & 20.00 & $49,121.50$ & 5.59 & 3.40 \\
\hline 2018 & $12,177.00$ & 23.48 & $10,578.80$ & 20.40 & $51,856.86$ & 5.57 & 2.80 \\
\hline 2019 & $12,283.30$ & 22.62 & $11,401.70$ & 21.00 & $54,293.81$ & 4.70 & 2.90 \\
\hline 2020 & $12,635.60$ & 25.71 & $10,961.80$ & 22.30 & $49,156.05$ & -9.46 & -8.00 \\
\hline$\varnothing$ & $8,761.20$ & 23.37 & $7,830.61$ & 20.89 & $37,482.39$ & 4.38 & 2.17 \\
\hline
\end{tabular}

Table 3 (Cont'd) Source: Author's calculation based on Eurostat Database, 2021

Figure 1. The trend of GCF, GFCF, and GCF-GFCF line, Croatia (in millions of Euros)

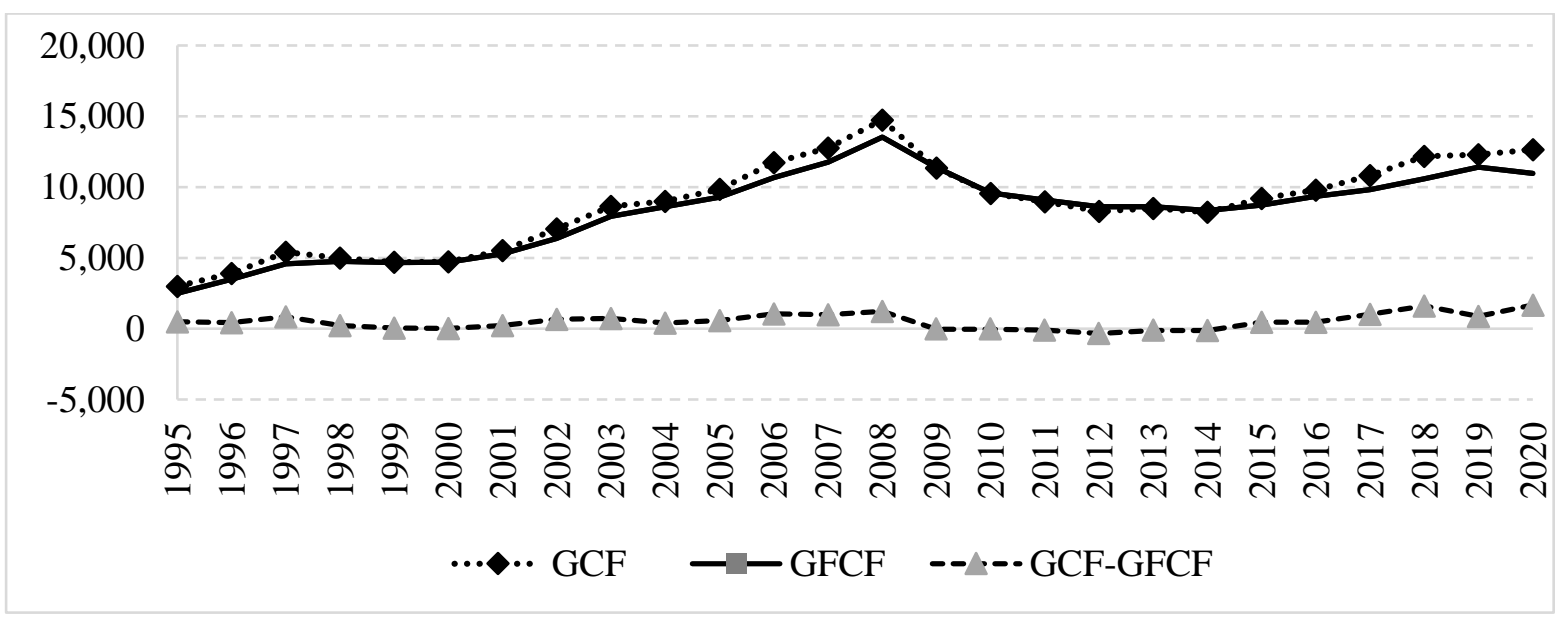

Source: Authors' work based on Eurostat Database, 2021

Data, Investments background and GDP growth in the Republic of Slovenia

The investments and economic growth on the economy of the Republic of Slovenia during the period 1995 - 2020 have had a positive trend with three breakpoints on years 2009 and 2019 (see Table 4):

- There is a positive trend of GCF, where $\mathrm{GCF}_{\mathrm{Min}}=4.16$ billion $€$ in the year $1995, \mathrm{GCF}_{\mathrm{Max}}=12.47$ billion $€$ in the year 2008, and a GCF average of 7.66 billion $€$ with an average of $23.90 \%$ of GDP.

- There is a positive trend of GFCF, where $\mathrm{GFCF}_{\text {Min }}=3.78$ billion $€$ in the year 1995 , $\mathrm{GFCF}_{\mathrm{Max}}=11.16$ billion $€$ in the year 2008, and a GFCF average of 7.83 billion $€$ with an average of $20.89 \%$ of GDP.

- There is a positive trend of nominal GDP growth rate from 1996 until 2008 and from the year 2010 until the year 2019. During the analyzed period the negative GDP growth rate is recorded in the years $2009(-4.42 \%), 2012(-2.23)$, and $2020(-4.58 \%)$. 
Table 4. GCF, GFCF, and GDP growth of the Republic of Slovenia

\begin{tabular}{|c|c|c|c|c|c|c|c|}
\hline Year & $\begin{array}{c}\text { GCF } \\
(\text { mil } €)\end{array}$ & $\begin{array}{c}\text { GCF } \\
(\% \text { of GDP })\end{array}$ & $\begin{array}{l}\text { GFCF } \\
(\mathrm{mil} €)\end{array}$ & $\begin{array}{c}\text { GFCF } \\
(\% \text { of GDP) }\end{array}$ & $\begin{array}{l}\text { GDP } \\
(\text { mil } €)\end{array}$ & $\begin{array}{c}\text { GDP nom } \\
\text { (a.g. } \%)\end{array}$ & $\begin{array}{c}\text { GDP real } \\
\text { (a.g. } \% \text { ) }\end{array}$ \\
\hline 1995 & $4,161.20$ & 25.44 & $3,778.90$ & 23.10 & $16,358.90$ & n.d. & n.d. \\
\hline 1996 & $4,254.60$ & 25.14 & $4,044.60$ & 23.90 & $16,923.01$ & 3.45 & 3.20 \\
\hline 1997 & $4,799.50$ & 26.22 & $4,612.30$ & 25.20 & $18,302.78$ & 8.15 & 5.00 \\
\hline 1998 & $5,380.60$ & 27.16 & $5,170.40$ & 26.10 & $19,809.96$ & 8.23 & 3.30 \\
\hline 1999 & $6,181.20$ & 29.13 & $5,877.00$ & 27.70 & $21,216.61$ & 7.10 & 5.30 \\
\hline 2000 & $6,320.00$ & 28.89 & $5,994.90$ & 27.40 & $21,879.20$ & 3.12 & 3.70 \\
\hline 2001 & $6,201.60$ & 26.72 & $6,126.40$ & 26.40 & $23,206.06$ & 6.06 & 3.20 \\
\hline 2002 & $6,354.10$ & 25.47 & $6,136.40$ & 24.60 & $24,944.72$ & 7.49 & 3.50 \\
\hline 2003 & $6,971.90$ & 26.53 & $6,570.10$ & 25.00 & $26,280.40$ & 5.35 & 3.00 \\
\hline 2004 & $7,974.60$ & 28.78 & $7,204.20$ & 26.00 & $27,708.46$ & 5.43 & 4.40 \\
\hline 2005 & $8,288.50$ & 28.47 & $7,744.50$ & 26.60 & $29,114.66$ & 5.07 & 3.80 \\
\hline 2006 & $9,534.60$ & 30.24 & $8,733.20$ & 27.70 & $31,527.80$ & 8.29 & 5.70 \\
\hline 2007 & $11,590.60$ & 33.10 & $10,049.00$ & 28.70 & $35,013.94$ & 11.06 & 7.00 \\
\hline 2008 & $12,472.10$ & 32.84 & $11,166.50$ & 29.40 & $37,981.29$ & 8.47 & 3.50 \\
\hline 2009 & $8,502.20$ & 23.42 & $8,748.50$ & 24.10 & $36,300.83$ & -4.42 & -7.50 \\
\hline 2010 & $8,131.60$ & 22.38 & $7,666.10$ & 21.10 & $36,332.23$ & 0.09 & 1.30 \\
\hline 2011 & $8,038.00$ & 21.64 & $7,391.10$ & 19.90 & $37,141.21$ & 2.23 & 0.90 \\
\hline 2012 & $6,800.80$ & 18.73 & $6,899.60$ & 19.00 & $36,313.68$ & -2.23 & -2.60 \\
\hline 2013 & $7,140.20$ & 19.55 & $7,157.30$ & 19.60 & $36,516.84$ & 0.56 & -1.00 \\
\hline 2014 & $7,291.30$ & 19.37 & $7,191.00$ & 19.10 & $37,649.21$ & 3.10 & 2.80 \\
\hline 2015 & $7,445.60$ & 19.21 & $7,247.80$ & 18.70 & $38,758.29$ & 2.95 & 2.20 \\
\hline 2016 & $7,452.40$ & 18.45 & $7,028.70$ & 17.40 & $40,394.83$ & 4.22 & 3.20 \\
\hline 2017 & $8,622.00$ & 20.03 & $7,877.40$ & 18.30 & $43,045.90$ & 6.56 & 4.80 \\
\hline 2018 & $9,713.70$ & 21.14 & $8,821.60$ & 19.20 & $45,945.83$ & 6.74 & 4.40 \\
\hline 2019 & $10,026.80$ & 20.68 & $9,503.00$ & 19.60 & $48,484.69$ & 5.53 & 3.20 \\
\hline 2020 & $9,533.90$ & 20.61 & $9,206.60$ & 19.90 & $46,264.32$ & -4.58 & -5.50 \\
\hline$\varnothing$ & $7,660.91$ & 23.90 & $7,228.73$ & 22.55 & $32,054.45$ & 4.32 & 2.43 \\
\hline
\end{tabular}

Table 4. (continued), Source: Author's calculation based on Eurostat Database, 2021

If we will analyse the trend lines of GCF and GFCF in Slovenia (see Chart 2), we can show that from the year 1995 to the year 2008 these lines are approximately in the same growth tendency. But, with a greater difference of GCF and GFCF in the year 2008. From the year 2009 as a result of the impact of the global financial crisis until 2012 these indicators have reduced. Unfortunately, during the years 2009, 2012 and 2013 Slovenian economy has marked a negative net investment. The situation has improved from the year 2013, with a growing tendency until the year 2019. In the year 2019, we were faced with the COVID-19 pandemic. This COVID-19 pandemic disrupted a lot of economic and financial indicators. 
Figure 2. The trend of GCF, GFCF, and GCF-GFCF line, Slovenia (in millions of Euros)

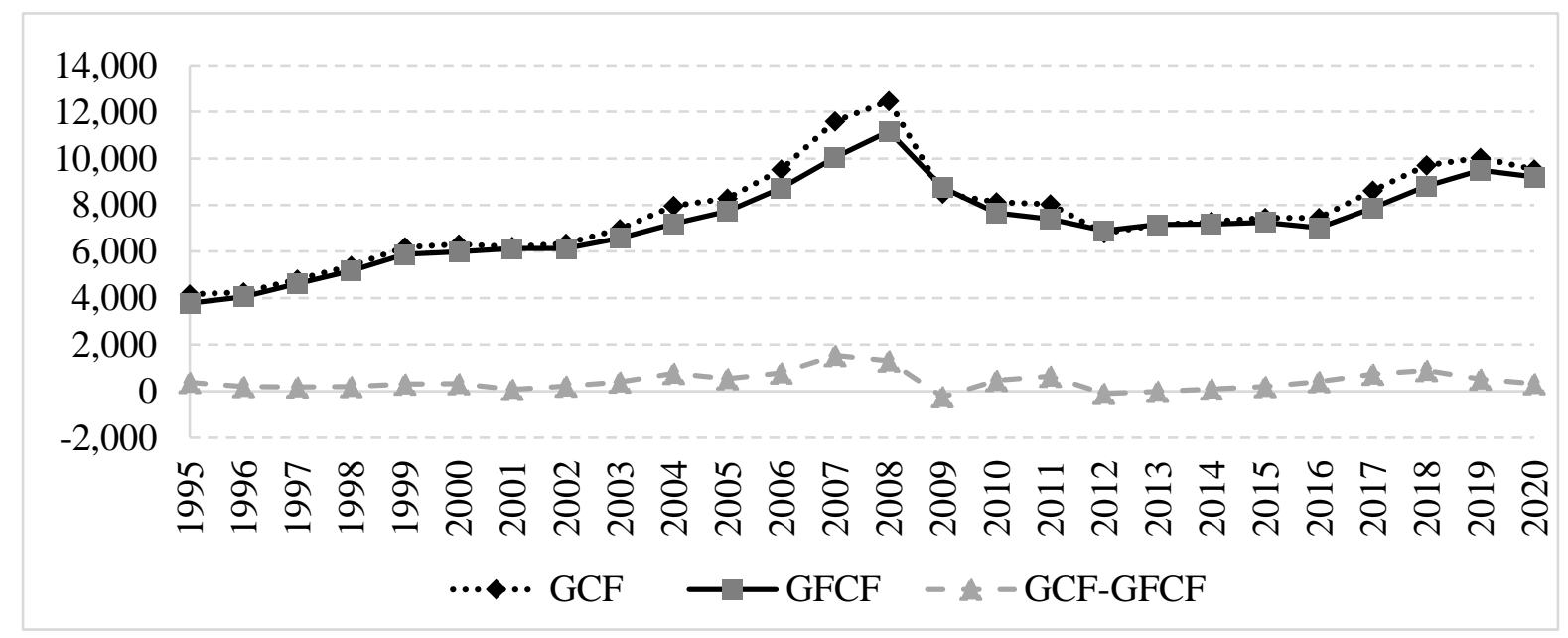

Source: Authors' work based on Eurostat Database, 2021

\section{Measuring of the ICOR score and a comparative analysis between the Republic of Croatia and Slovenia}

To assess the most accurate level of investment efficiency between Croatia and Slovenia we will analyze and compare the ICOR score and nominal rate of GDP growth during the research period.

The economy of Croatia during the analyzing period has marked a good performance based on ICOR and GDP annual growth, except on the years 1999, 2009, 2010, and 2019.

From the measurement of ICOR during 25 years (from 1996 until 2020) presented in Table 5 and Chart 3, we can withdraw the following:

- The best ICOR score (0-1.99), is on 2 years (1996 and 1997).

- The good ICOR score (2-3.99), is on 12 years (2002, 2001, 2020, 2006, 2005, 2003, 2007, 2008, 2000, 1998, 2017 and 2018).

- The low ICOR score (4-5.99), is on 3 years (2019, 2016, and 2015).

- The weak ICOR score $(>6)$ is in the year 2010.

- The negative ICOR score is on 7 years (2011, 2013, 2014, 2010, 1999, and 2009). These years are characterized by the recession period of Croatia.

Table 5. ICOR score and correlation with a nominal rate of GDP growth, Croatia \& Slovenia

\begin{tabular}{|c|c|c|c|c|c|}
\hline Year & $\begin{array}{c}\text { GDP (n.a.g.\%) } \\
(\text { HR })\end{array}$ & $\begin{array}{c}\text { ICOR } \\
(\text { HR })\end{array}$ & $\begin{array}{c}\text { Best ICOR } \\
\text { score }\end{array}$ & $\begin{array}{c}\text { ICOR } \\
(\text { SI })\end{array}$ & $\begin{array}{c}\text { GDP (n.a.g.\%) } \\
(\text { SI) }\end{array}$ \\
\hline 1996 & 8.92 & 1.93 & Croatia & 7.38 & 3.45 \\
\hline 1997 & 11.06 & 1.86 & Croatia & 3.08 & 8.15 \\
\hline 1998 & 7.72 & 3.32 & Slovenia & 3.18 & 8.23 \\
\hline 1999 & -3.55 & -6.16 & $(-/+)$ Slovenia $*$ & 3.83 & 7.10 \\
\hline 2000 & 6.48 & 3.31 & Croatia & 9.33 & 3.12 \\
\hline 2001 & 9.80 & 2.06 & Croatia & 4.76 & 6.06 \\
\hline 2002 & 10.56 & 2.03 & Croatia & 3.57 & 7.49 \\
\hline 2003 & 8.17 & 3.03 & Croatia & 4.76 & 5.35 \\
\hline 2004 & 8.85 & 3.18 & Croatia & 4.88 & 5.43 \\
\hline 2005 & 9.17 & 2.94 & Croatia & 5.67 & 5.07 \\
\hline
\end{tabular}




\begin{tabular}{|c|c|c|c|c|c|}
\hline 2006 & 9.97 & 2.70 & Croatia & 3.43 & 8.29 \\
\hline 2007 & 9.37 & 3.12 & Slovenia & 2.74 & 11.06 \\
\hline 2008 & 9.20 & 3.16 & Croatia & 3.91 & 8.47 \\
\hline 2009 & -5.96 & -5.16 & $(-/-)$ Croatia** & -7.42 & -4.42 \\
\hline 2010 & 0.12 & 215.47 & Croatia & 270.79 & 0.09 \\
\hline 2011 & -0.57 & -36.91 & $(-/+)$ Slovenia & 10.05 & 2.23 \\
\hline 2012 & -2.08 & -9.61 & $(-/-)$ Croatia & -9.71 & -2.23 \\
\hline 2013 & -0.59 & -31.99 & $(-/+)$ Slovenia & 33.48 & 0.56 \\
\hline 2014 & -0.94 & -20.66 & $(-/+)$ Slovenia & 6.31 & 3.10 \\
\hline 2015 & 3.30 & 5.76 & Croatia & 6.57 & 2.95 \\
\hline 2016 & 4.01 & 5.12 & Slovenia & 4.55 & 4.22 \\
\hline 2017 & 5.59 & 3.77 & Slovenia & 2.81 & 6.56 \\
\hline 2018 & 5.57 & 3.96 & Slovenia & 2.97 & 6.74 \\
\hline 2019 & 4.70 & 5.00 & Slovenia & 3.83 & 5.53 \\
\hline 2020 & -9.46 & -2.39 & $(-/-)$ Croatia & -4.52 & -4.58 \\
\hline & Correlation (HR) & $\mathbf{- 0 . 0 1 9 0 2}$ & & Correlation (SI) $\mathbf{- 0 . 1 9 8 1 7}$ \\
\hline
\end{tabular}

Table 5. (Cont'd)Source: Author's calculation based on Eurostat Database, 2021

* (-/+) ICOR Slovenia = ICOR of Slovenia is a positive but ICOR of Croatia is a negative

** (-/-) ICOR Croatia = Best ICOR for Croatia where both countries have a negative ICOR

Chart 3. The trend of ICOR (right axis) and nominal GDP growth (\%) (left axis), Croatia

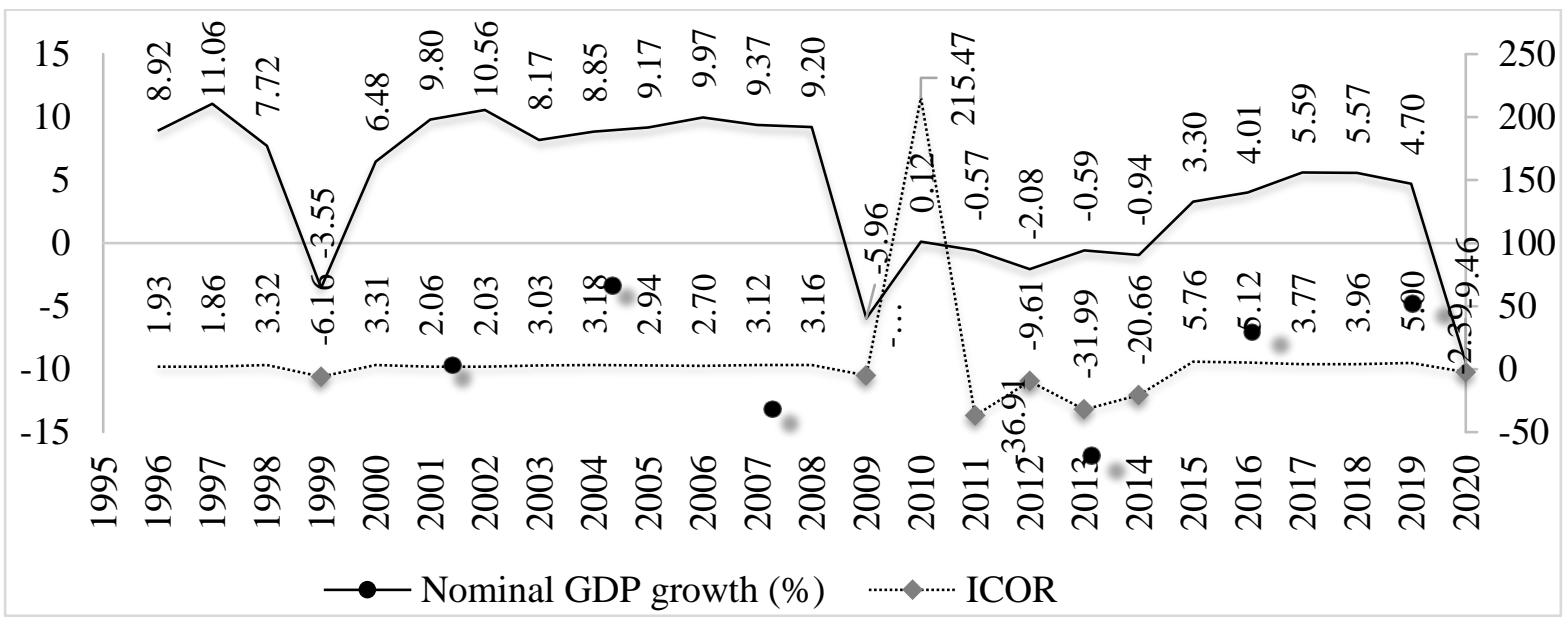

Source: Authors' work based on Eurostat Database, 2021

The economy of Slovenia during the period of analysis has noted a good performance of nominal GDP growth based on ICOOR, except on the years 1999, 2009, 2010, and 2019.

From the measurement of ICOR in Slovenia during 25 years (from 1996 until 2020) presented in Chart 4 and 5, we can withdraw the following:

- Have not the best ICOR score (0-1.99) during the period,

- The good ICOR score (2-3.99), are on 10 years $(2007,2017,2018,1997,1998,2006,2008,2019$, 2002 and 1999)

- The low ICOR score (4-5.99), is on 5 years $(2016,2001,2003,2004$ and 2005

- The weak ICOR score (>6) is on 7 years $(2014,2015,1996,2000,2011,2013$, and 2010).

The negative ICOR score is on 3 years $(2020,2009,2012)$. These years are characterized by the recession period of Slovenia.

Chart 4. The trend of ICOR (right axis) and nominal GDP growth (\%) (left axis), Slovenia 


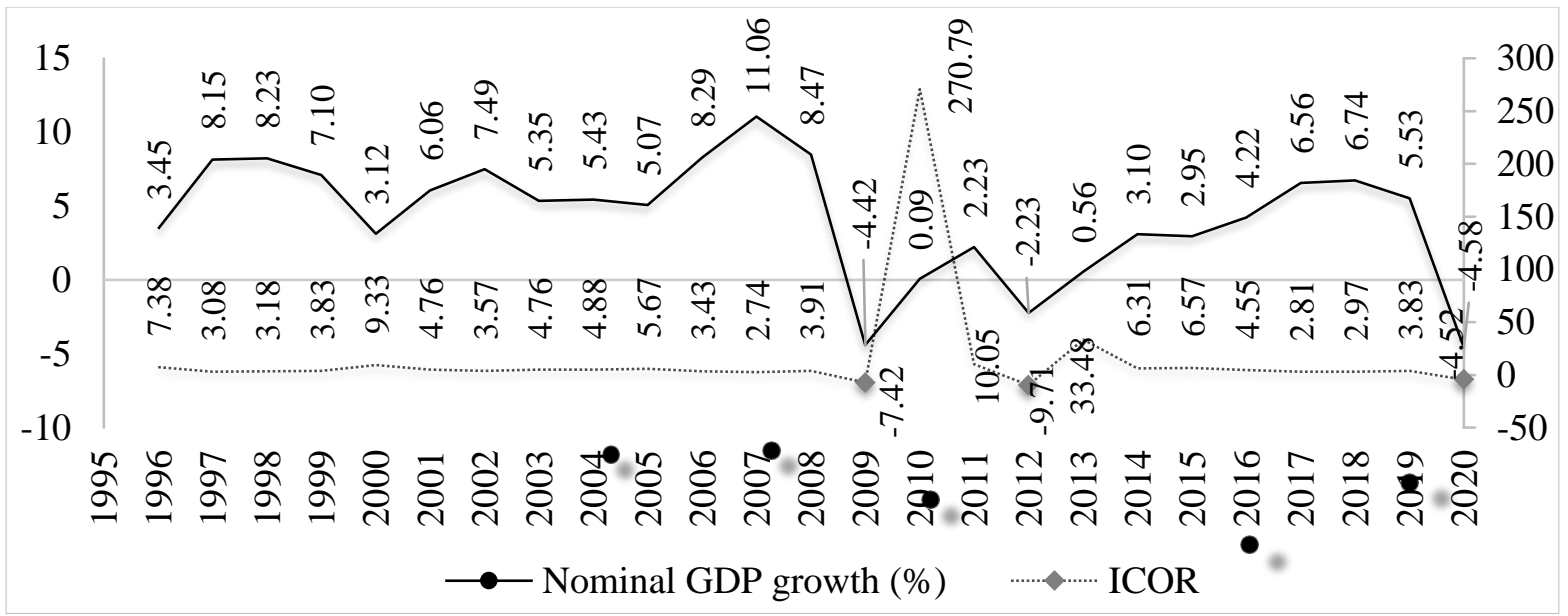

Source: Authors' work based on Eurostat Database, 2021

\section{Results and Discussion}

Based on research measured in Table 5, on one hand, we can say that some of the ICOR values in both countries are negative (7-years for Croatia and 3-years for Slovenia), therefore ICOR values of these years aren't significant. In this case, Croatia for the same 4 years as Slovenia has noted a negative ICOR versus a positive ICOR for Slovenia (for this year Slovenia has the best efficiency of investment). Comparison values between Croatian and Slovenian ICOR for the analyzed period are expressed as follows (Chart 5):

Figure 5. ICOR evaluation, Republic of Croatia (HR) vs Slovenia (SI) (1996-2020)

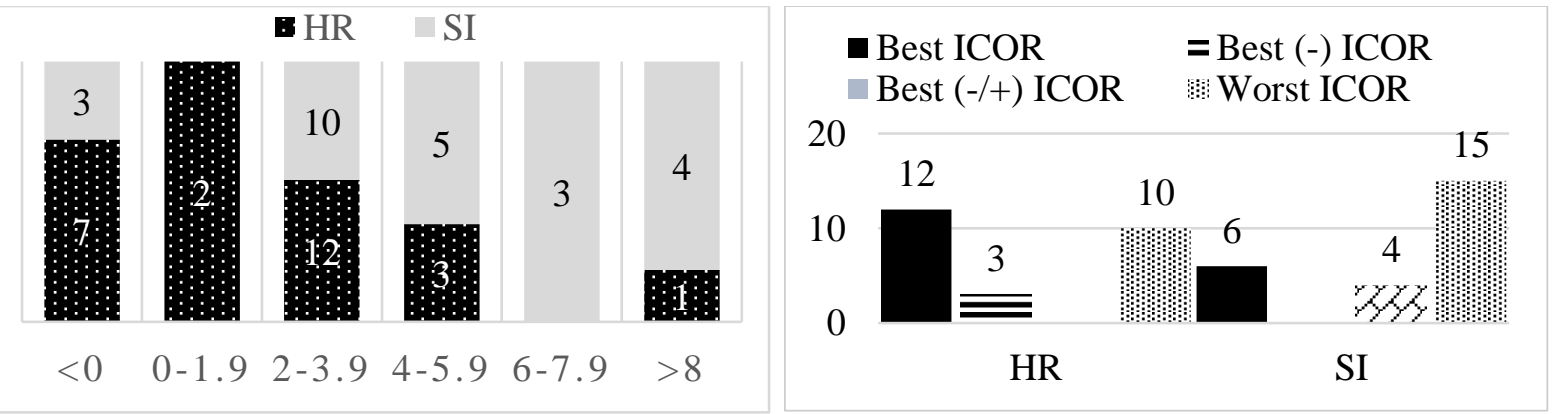

Source: Author's calculation based on Eurostat Database, 2021

The findings of the last analysis include the following:

- The Republic of Croatia has 12 best ICOR score versus 6 of Slovenia

- The Republic of Croatia has the 3 best ICOR scores versus Slovenia when both countries have a negative ICOR value (Best [-/-] ICOR) (although when the value is negative it does not matter to discuss).

- The Republic of Slovenia has the 4 best ICOR scores versus Croatia in conditions when Croatia has a negative ICOR while Slovenia has a positive ICOR (Best [-/+] ICOR).

- The Republic of Croatia has the Worst ICOR score for 10 years while the Republic of Slovenia has it for 15 years.

In our estimation, we did not take into consideration the negative values of ICOR and GDP growth as well as 2010 and 2020 as years of global financial crisis and COVID19, respectively (see Appendix, Chart 6). 
The research concludes that there is a negative correlation between ICOR and economic growth $(\mathrm{g})$ in Croatia with -0.931 and is higher than in Slovenia -0.668 (see Table 6). Results for both countries are statistically significant $(\mathrm{p}<0.0001)$ and according to the ICOR rule. The finding has a slightly different estimation from the one depicted in Table 5 which utilized the negative values of ICOR.

Table 6. Index of correlation between economic growth (g) and ICOR, Croatia \& Slovenia

\begin{tabular}{|lcc|}
\hline & gh & ICORh \\
\hline gh & 1 & \\
ICORh & $-0.931^{* * *}$ & 1 \\
\hline$*$ p $<0.05, * *$ & $p<0.01, * * *$ & $p<0.001$ \\
\hline
\end{tabular}

\begin{tabular}{|lcc|}
\hline & gs & ICORs \\
\hline gs & 1 & \\
ICORs & $-0.668^{* * *}$ & 1 \\
\hline$* \mathrm{p}<0.05, * *$ & $\mathrm{p}<0.01, * * *$ & $\mathrm{p}<0.001$ \\
\hline
\end{tabular}

Source: Authors' calculation

For estimation of the regression of the one-factor econometric model for both countries, we will use the STATA-16 application with a heteroscedasticity control and normal distribution (see Appendix, Chart 7). As a result of the conducted regression, we obtained these results (see Table 7 and Table 8):

Table 7. Regression between economic growth (g) and ICOR (Slovenia)

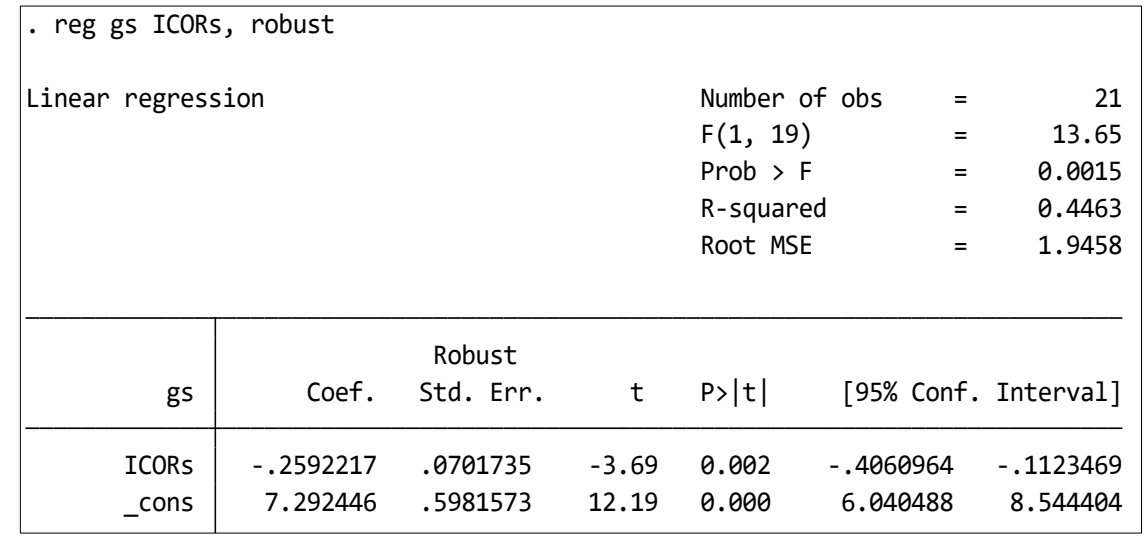

Source: Authors' Authors' calculation

In Table 7 we show the results of regression economic growth and ICOR Slovenia. By substituting these values in equation one-factorial model "(2)", we will obtain the equation that can be used to predict the value of the economic growth $(\mathrm{g})$ as a dependant variable based on an ICOR value as an independent variable.

The equation is fitted as follow:

$$
g_{(\%) S I}=7.292446-0.2592217 \times I C O R_{S I}
$$

\section{Interpretation of regression results:}

- The value of Prob (F) is the p-value of the model. This is the p-value of the model. It tests whether $\mathrm{R}$-square is different from 0 . Usually, it needs a p-value to be lower than 0.05. In our case, it's 0.0015 and shows a statistically significant relationship between ICOR and g (\%) (Slovenia).

- R-square shows that the variance of economic growth is explained $44.63 \%$ by ICOR level.

- For each one-point decrease in ICORE level, economic growth scores increase by 0.259 percent. 
- The $t$-value tests the hypothesis that the coefficient is different from 0 . To reject this needs an at-value greater than 1.96 (for 95\% confidence). The t-value of ICOR Slovenia is -3.69 and higher than 1.96 which shows the importance of the ICOR coefficient's -0.2592217 in the model.

- P-values test the hypothesis that each coefficient is different from 0 . To reject this, the p-value has to be lower than $0.025(\alpha / 2=2.5 \%$ ), you could choose also an $\alpha / 2=5 \%$ (P-value $=0.05)$. In our case, Pvalue is $0.002<0.025$, ICOR is statistically significant in explaining economic growth.

Table 8. Regression between economic growth (g) and ICOR (Croatia)

\begin{tabular}{|c|c|c|c|c|c|c|c|}
\hline \multicolumn{8}{|c|}{. reg gh ICORh, robust } \\
\hline \multirow{3}{*}{\multicolumn{4}{|c|}{ Linear regression }} & \multirow{3}{*}{\multicolumn{2}{|c|}{$\begin{array}{l}\text { Number of obs } \\
\mathrm{F}(1,15) \\
\text { Prob }>\mathrm{F} \\
\text { R-squared } \\
\text { Root MSE }\end{array}$}} & $=$ & 17 \\
\hline & & & & & & $=$ & 0.8667 \\
\hline & & & & & & $=$ & .90198 \\
\hline & & Robust & & & & & \\
\hline gh & Coef. & Std. Err. & $\mathrm{t}$ & $P>|t|$ & {$[95 \%$} & Conf. & Interval] \\
\hline ICORh & -1.961057 & .1429079 & -13.72 & 0.000 & -2.26 & 5658 & -1.656456 \\
\hline _cons & 14.27938 & .5890494 & 24.24 & 0.000 & 13.0 & & 15.53491 \\
\hline
\end{tabular}

Source: Authors' calculation

The final calculated regression values in Table 8 are dedicated to Croatia. Transformation of the equation "(2)" based on results mentioned in the table above will obtain the fitted following form:

$$
g_{(\%) H R}=14.27938-1.961057 \times I C O R_{H R}
$$

Interpretation of regression results:

- The Prob (F) value is 0.0000 and shows a statistically significant relationship between ICOR and g (\%) (Croatia).

- R-square shows that the variance of economic growth is explained $89.67 \%$ by ICOR level.

- For each one-point decrease in ICORE level (Croatia), economic growth scores (Croatia) increase by 1.961 percent.

- The t-value of ICOR Croatia is -13.27 and higher than 1.96 which shows the importance of the ICOR coefficient's -1.961057 in the model.

- The p-values are $0.000<0.05$, ICOR is statistically significant in explaining economic growth.

According to our findings, we will reject the first assumption that the Republic of Slovenia has better investment efficiency compared to Croatia. It turned out that the Republic of Croatia is more investment efficient than Slovenia. The ICOR level of Croatia for each one-point decrease, increases economic growth by 1.961 percent, while ICOR level of Slovenia increases less the economic growth by 0.259 percent.

\section{Concluding Remarks}

In the ex-YU republics, there are a small number of research papers dedicated to investment efficiency. This research is one of those few works which elaborates on these issues. The basic principle of ICOR is that if any economy reaches the lowest level of ICOR value, it shows the highest degree of efficiency of investments in that economy and is in the right way to increase economic growth. 
According to the findings of our research dedicated to the Republic of Croatia and the Republic of Slovenia, we can summarise as follows:

- During the analyzing period (1996-2020), both countries have noted a negative value of ICOR. The Republic of Croatia has recorded a negative value of ICOR in 7 from 25 years $32 \%$ of the analyzing period. While the Republic of Slovenia in 3 from 25 years or $12 \%$ of the analyzing period. These values are not significant for commenting-related investments efficiency.

- Values of ICOR into the interval 0-1,99 as the best score, in Croatia, are encountered in 2 years, and in no years in Slovenia, expressed as a percentage $8 \%$ for Croatia.

- Values of ICOR into the interval 2-3,99 as a good score, in Croatia, are encountered in 7 years, and in Slovenia in 3 years, expressed this as a percentage is $28 \%$ and $12 \%$, respectively.

- Values of ICOR into the interval 4-5,99 as a low score, in Croatia, are encountered in 3 years, and Slovenia in 5 years, expressed this as a percentage is $12 \%$ and $20 \%$, respectively.

- Value of ICOR more than 6 consider as a weak score. In Croatia are encountered in a year, in Slovenia in 7 years, expressed this as a percentage is $4 \%$ and $28 \%$, respectively.

From the above summary of the two economies, Croatia and Slovenia, we have the right to conclude as follows:

- There is a very strong negative relationship between ICOR and economic growth (g) in Croatia with a correlation index of -0.931 and a strong relationship in Slovenia with a correlation index of -0668. This disproportionate ratio shows that decreasing the ICOR level impact increasing the rate of GDP growth.

- In a condition where we have not taken into consideration the negative values of ICOR as well as 2010 and 2020 as years of the global financial crisis of COVID19, it results that the mean of ICORE of Croatia and Slovenia marks value around 3.51 and 6.55, respectively.

- The impact level of ICOR on the economic growth of Croatia and Slovenia shows that each onepoint decrease of the ICOR, should increase Croatia's economic growth by 1.961 and 0.259 percent of Slovenia's economic growth. It follows that there is a difference of 1.702 percent points in favor of the Republic of Croatia.

Some of the findings of this research are in the same direction as the findings of the other authors such are Lovrinčević et al. (2004), Antiochou (2011), Gabrisch (2014) and Ivanović, Igor (2015), Mazllami \& Aziri (2019).

While all research papers have certain limitations, these research papers' limitations include the relatively small number of variables of the ICOR ratio, as well as the utilization of the simple model of econometric approach. All these limitations will present an additional opportunity for my future research.

\section{References}

Antiochou, Effie. (2011). Medium-Term Projections of Investment in the Western Balkans. EIB Working Paper. Retrieved from https://institute.eib.org/wpcontent/uploads/2019/02/STAREBEI-Sophiaall.pdf

Barro, Robert J. (1988). Government Spending in a Simple Model of Endogenous Growth. RCER Working Papers from the University of Rochester (RCER). Retrieved from https://ideas.repec.org/p/roc/rocher/130.html

Bencivenga, Valerie R., \& Bruce D. Smith. (1991). Financial Intermediation and Endogenous Growth. Review of Economic Studies. 1991, Vol. 58, 195-209. Retrieved from http://hdl.handle.net/10.2307/2297964

Berthomieu, Claude at al. (2016). Investment for Growth and Development in the Western Balkans. STAREBEI Research Project EIB Institute University of Nice - Sophia Antipolis (France). Retrieved from https://institute.eib.org/wp-content/uploads/2019/02/STAREBEI-Sophiaall.pdf 
Domar, Evsey D. (1946). Capital Expansion, Rate of Growth, and Employment. Econometrica, Vol. 14, No. 2,137-147. Retrieved from http://www.jstor.org/stable/1905364

Eurostat Database. (2021). Gross capital formation, Gross fixed capital formation, and GDP growth rate. Data extracted on 28/03/2021 23:45:01 from [ESTAT].

Gabrisch, Hubert. (2014). The binding constraint on growth in less developed Western Balkan countries. MPRA Paper No. 60020. Retrieved from https://mpra.ub.uni-muenchen.de/60018/

Harrod, Roy F. (1939). An Essay in Dynamic Theory. The Economic Journal, Vol. 49, No. 193, 14-33. Retrieved from http://piketty.pse.ens.fr/files/Harrod1939.pdf

Ivanović, Igor. (2015). Impact of Foreign Direct Investment (FDI) on Domestic Investment in the Republic of Croatia. Review of Innovation and Competitiveness, Volume 1, Issue 1. Retrieved from https://mpra.ub.uni-muenchen.de/70076/1/MPRA paper 70076.pdf

Kaldor, Nicholas. (1957). A Model of Economic Growth. Economic Journal, Volume 67, Issue 268, 591-624. https://doi.org/10.2307/2227704

Lovrinčević Željko, et al. (2004). Investment efficiency and FDI - Old story, new circumstances. Economic Review, Vol.55, 1-43. Retrieved from https://hrcak.srce.hr/14800

Lucas, Robert E. Jr. (1988). On The Mechanics of Economic Development. Journal of Monetary Economics, Vol. 22, 3-42. https://doi.org/10.1016/0304-3932(88)90168-7

Mazllami, J., \& Aziri, B. (2019). Investments efficiency and economic growth: a comparative analysis of North Macedonia and Albania. Knowledge International Journal,31(5), 1381-1389. Retrieved from https://ikm.mk/ojs/index.php/KIJ/article/view/1284

Mazllami, Jeton. (2007). The economic efficiency of investment in the Republic of Macedonia during the transition period with a specific emphasis on the Polog region. Master thesis Faculty of Economics Skopje (unpublished).

Nikolic, I., \& Kovacevic, M. (2019). Prospects and limits to growth: The importance of investment efficiency? Ekonomika preduzéca, vol. 67, br. 5-6, str. 297-318. Retrieved from https://scindeks.ceon.rs/article.asp $x$ ?artid $=0353-443 X 1905297 \mathrm{~N}$

Phelps, Edmund. (1961). The Golden Rule of Accumulation: A Fable for Growthmen. The American Economic Review, Vol.51, No4, 638-643. Retrieved from https://www.jstor.org/stable/1812790

Romer, Paul M. (1986). Increasing Returns and Long-Run Growth. The Journal of Political Economy, Vol. 94, No. 5, 002-1037. Retrieved from http://www.dklevine.com/archive/refs42232.pdf

Setterfield, Marc. (2010). Handbook of Alternative Theories of Economic Growth. Cheltenham: Edward Elgar.

Solow, Robert M. (1956). A Contribution to the Theory of Economic Growth. The Quarterly Journal of Economics, Vol. 70, No.1, 65-94. Retrieved from http://piketty.pse.ens.fr/files/Solow1956.pdf

Vinski, Ivo. (1961). National product and fixed assets in the territory of Yugoslavia 1909-1959", Review of Income and Wealth, Vol. 9 (1), 206-233. https://doi.org/10.1111/j.1475-4991.1961.tb01135.x

World Bank. (2018). Long Term Growth Model (LTGM v4.1) - Model Description 


\section{Appendix:}

Chart 6. Trend lines of ICOR vs Economic growth rate, Republic of Croatia (HR) and Slovenia (SI), (1996-2020)*
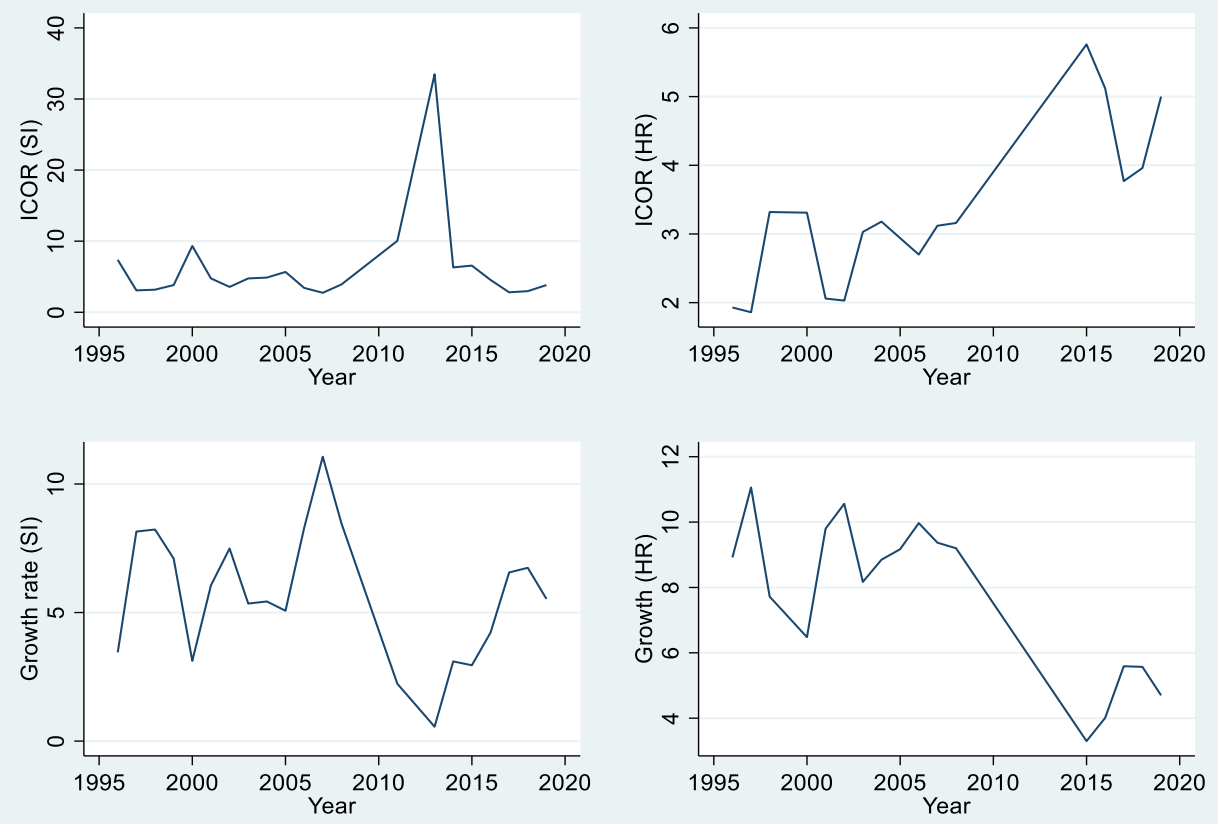

Source: Authors' own work

Chart 7. Histogram and line of normal distributions of residual, kdensity - a model of Slovenia and Croatia

Source: Authors' own work
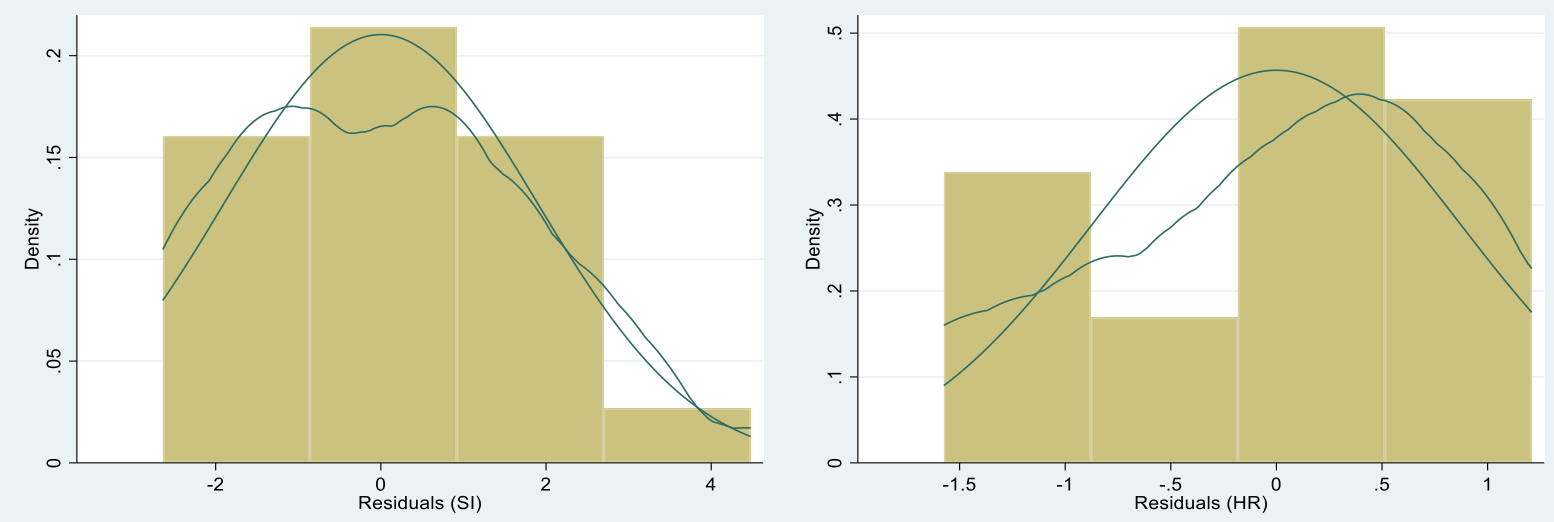